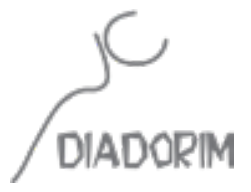

\title{
INTERNATIONALIZATION OF LANGUAGES AND CULTURE OF INDIGENOUS PEOPLES OF THE ARCTIC IN THE GLOBAL INTERNET
}

\author{
Anatoly Zhozhikov ${ }^{1} \&$ Borisova Isabella Zakharovna ${ }^{2}$
}

\begin{abstract}
As globalization expands, the phenomenon of languages disappearance is becoming more critical. In the context of the information society development, the clash of globalization and national identity is acute. Information and communication technologies play an extremely important role in the balance of power between competing languages, and here the dominant languages have advantages to the detriment of others. To eliminate these trends, it is necessary to take urgent measures to support minority languages that are on the verge of extinction. This paper discusses ways to solve the problem and represent the languages and cultures of the indigenous peoples of the North and the Arctic on the global Internet. The article is devoted to the internationalization of the languages and cultures of the indigenous people of the North and the Arctic through the global Internet. The purpose of the study is the creation and use of the multilingual Internet portal www.arctic-megapedia.ru, which should integrate the languages and cultures of all indigenous peoples of the North and the Arctic in the global information space to the new multicultural communication of XXI century. For the implementation of the project, an internationalization model was used based on the terms "internationalization" and "localization" and their concepts adopted in computer science. The project "Digitalization of the Linguistic and Cultural Heritage of Indigenous Peoples of the Arctic" will be submitted to the Arctic Council for implementation in 2020-2023. Multilingual portal www.arctic-megapedia.ru should become a part of the world multicultural environment and organically integrate the languages and culture of the indigenous peoples of the North and the Arctic into the global information space so that they can fully represent their people, native language and culture in this multicultural environment of humankind. Localization of the project will be implemented by the creation of regional Internet resources on indigenous peoples, living in these territories and countries, subsequently integrated on a unified multilingual online portal www. arctic-megapedia.ru. The implementation of the project will be focused on promoting the achievement of the sustainable development goals of the indigenous peoples of the Arctic in the context of globalization. Keywords: Globalization; information and communication technologies; the Internet; multicultural environment; small-numbered nations, internationalization, indigenous peoples of the North and the Arctic.
\end{abstract}

\footnotetext{
1 M.K. Ammosov North-Eastern Federal University / UNESCO Chair "Social and Human Adaptation of the Arctic Regions to Climate Changeand Globalization" / Cátedra UNESCO "Políticas Linguísticas para o Multilinguismo" (UNESCO Chair "Language Policies for Multilingualism")

2 Research Associate Professor -Yakutsk State North-Eastern Federal University / UNESCO Chair "Social and Human Adaptation of the Arctic Regions to Climate Changeand Globalization" / Cátedra UNESCO "Políticas Linguísticas para o Multilinguismo" (UNESCO Chair "Language Policies for Multilingualism")
} 


\section{Opportunities and role of information and communication technologies in the preservation and development of languages and culture in the global information space}

The development of new high-tech equipment, in particular computer equipment, characterized by high efficiency of working with information and the development of network technologies have led to the emergence of a fundamentally new information and communication environment - the global Internet. The modern global computer network, the Internet, has become an essential part of the infrastructure of modern society. Based on the technology of computer data transmission, the Internet has become an effective medium for mass communication, differing from previous information and communication media in important features, primarily enhanced capabilities in the presentation of information due to hypertext, multimedia and interactivity [1, p.54-55].

The processes of globalization, in which the whole world is involved, are very ambiguous, but it is obvious that further integration into the world community is inevitable. In these conditions, it is extremely important to preserve the diversity of cultures and languages, because the preservation of cultural diversity is an indispensable condition for the sustainable development of society, peaceful and respectful coexistence of peoples.

The phenomenon of the disappearance of languages, which in the recent past was caused by such factors as colonization, genocide, epidemics, wars, population displacement, the ban on the use of languages, etc., is becoming more acute as globalization expands - economic, technological, social, political, etc.Communication plays an extremely important role in the balance of power between two competing languages, and in the information age this phenomenon is increasing: support is given to more adapted or more "prestigious" languages to the detriment of others.

The rapid development of the Internet has served as an impetus for the development of social networks, as a result of which a new multicultural communication environment has emerged, in which there are no borders, distances and time limits. Communication on the Internet, in principle, has become possible in almost all languages of the peoples of the world. Development of WWW, blogosphere, and digital libraries form a community to the production, exchange and dissemination of knowledge, global and local character. The Internet provides great opportunities for users in terms of ensuring freedom of opinions sharing, education, preservation and development of culture, spirituality.

Mobile communications have gained unprecedented development, the relevance of which has become even more effective due to their integration with the global Internet. The introduction of mobile applications such as Vkontakte and WhatsApp has gained widespread recognition, as a result of which a new environment for communication and efficient transfer of almost all types of information has begun to take shape. 
At the same time, in the context of the formation of the information society, it is necessary to pay special attention to the contradictions that arise between the global processes of the formation of the information society and the preservation of the national identity of any, even the small-numbered people. One of such contradictions, as noted [2, p.341-344], is the clash of globalization and national identity. Information and communication technologies (ICT), especially the global Internet, on the one hand, contribute to the development of globalization processes and the erasure of cultural and linguistic diversity, but, on the other hand, when used correctly, they can play an integrating role in building a new world order to discover new opportunities for the formation of a multicultural environment in the world information space that promotes dialogue and interaction of cultures, religions, as well as the preservation and development of languages and cultures of all peoples inhabiting our planet.

Each language is a unique repository of information about the ethnic group speaking it and its culture, about its own evolution, as well as about the nature of human as a biological species. Throughout the history of humankind, the birth of some languages and the death of others took place. In general, about 200 languages have disappeared in the world over the last three generations of human life - this is evidence of the new "Atlas of Endangered Languages" published by UNESCO. The new issue of UNESCO Courier, prepared for the International Mother Language Day (February 21, 2009), is dedicated to the alarming phenomenon: disappearing languages take away not only words, but also worldview systems, communication, valuable knowledge, whole worlds of different ways of thinking [3, p.111-129].

\section{Human in a new multicultural environment on the Internet}

Each person is brought up in a certain environment, the most important components of which become an integral part of the worldview of this person as a member of a certain community. Any national culture can be described as a certain way of thinking and acting, a way of spiritual perception of reality, which can be described using such parameters as selfawareness and space, attitude to time, language, clothes, food, behavioral norms, etc. Any culture or cultural environment of people is a way to adapt to the existing physical, social and biological environment.

At the same time, it should be noted that we live in a multicultural world, where each culture creates its own taboos and values, encouraged and forbidden norms of behavior, relationships, and where a culturally programmed human brain ignores what is contrary to this culture. This is a certain obstacle to the interaction of representatives of different cultures. Also, it should be noted that along with our traditional form of communication, a completely new multicultural communication environment is being formed on the Internet, which begins to prevail over conventional means of communication.

An inevitable condition for the effectiveness of communication between representatives 
of different cultures is understanding and respect for other cultural values, feelings and ideas. The first step towards understanding and recognizing existing cultural differences is to develop cultural tolerance and to recognize such a complex phenomenon as culture and its components, as it gives people a sense of identity, especially in terms of awareness of human behavior and recognized values. Knowledge of culture allows you to look at its representatives from the inside and apply a certain set of rules and etiquette in accordance with national or local traditions, norms, habits [4]. Therefore, a multicultural information environment should be formed on the global Internet, in which everyone, even the small-numbered peoples, will be represented.

Indigenous People and Arctic are the creators and custodians of a unique human culture and an important part of the modern world civilization. They are and remain carriers of adaptive life support systems in the harsh conditions of the Arctic and the Far North, distinctive traditions and unique spiritual values. The inhabitants of the North for many centuries mastered the Arctic landscapes, adapted to extreme natural and climatic conditions of permafrost, developed their original culture and lived in harmony with nature, without violating and preserving the ecology of vulnerable northern nature. However, the indigenous peoples of the North and the Arctic are more than anybody else facing the challenges of modern society: the deepening processes of globalization, technogenic processes, and the active industrial development of their original habitats have a devastating effect on the traditional way of life. The turbulent processes of globalization and industrial development of the North have led these peoples to be on the verge of an ethnic crisis that threatens to lose the unity of ethnic attributes (language, culture, lifestyle, traditional forms of economy: reindeer husbandry, hunting, fishing). All this significantly accelerates the pace of the extinction of languages and a catastrophic decrease in the number of native speakers of the indigenous peoples of the North and the Arctic, and the gradual loss of their distinctive cultural heritage. To eliminate these trends, it is necessary to take urgent measures to preserve and develop the languages and culture of the indigenous peoples of the North and represent them in the international information space, in the new multicultural communication environment of the 21 st century.

\section{Project implementation}

Taking this into account, at M.K. Ammosov North-Eastern Federal University, together with leading scientists of the Institute for Humanitarian Research and Indigenous Peoples' Issues of the Yakutsk Scientific Center of the Siberian Branch of the Russian Academy of Sciences, work has begun in 2011 to integrate indigenous languages and culture into the global information space. The implementation of this project was launched under the Development Program of the M.K. Ammosov North-Eastern Federal University entitled "The Program for the Preservation and Development of Languages and Cultures of Indigenous Peoples of the North on Digital Media and in Cyberspace" [5, p. 438-441]. 
At the first stage (2011-2013) of the project, expeditions were organized to the places of compact residence of indigenous peoples in the Republic of Sakha (Yakutia), for organizing video and photography of disappearing native speakers and cultures of indigenous peoples (Yukagir, Even, Evenki, Dolgan and Chukchi). The collected material is used in two directions:

1. creating digital educational multimedia DVDs on the language and culture of the indigenous peoples;

2. creating a publicly accessible multilingual portal of indigenous peoples of the North www.arctic-megapedia.ru.

Based on collected materials 18 educational DVDs on the language and culture of indigenous peoples living in the territory of the Republic of Sakha (Yakutia) created, mega portalof indigenous peoples www.arctic-megapedia.ru designed, on which almost all available materials are already posted.

Work in this area has shown great demand for the project not only in the Republic of Sakha (Yakutia), but also in other regions of the Russian Federation. This project was presented in March 2013 at the VII Congress of the Indigenous Peoples of the North, Siberia and the Far East, held in Salekhard, aroused great interest and support.

The indigenous Arctic multilingual portal www.arctic-megapedia.ru became a finalist of the Far Eastern Internet award "Sterkh" in the section "Best Non-Profit or Thematic Project of the Far East" in April 2013. The next stage of the project was the expansion of the project throughout the Far East. Expeditions were organized to record indigenous peoples on digital media: Chukotka (Chukchi, Eskimo), Kamchatka (Koryak and Itelmen) and Khabarovsk Territory (Nanai, Negidal and Udege). Within the framework of the expeditions, recordings of already almost disappearing native language speakers and culture bearers were made, locally available materials were collected. All this information is gradually placed on a portal www. arctic-megapedia.ru. In addition, on Facebook a group of indigenous peoples was created on the basis of the Arctic portal, where an environment for the exchange of information and communication of indigenous peoples is also being formed. The project is successfully developing and has received the support of the Russian Association of Indigenous Peoples of the North.

In recent years, the project has been presented, discussed and approved at the following international conferences:

1. VII International Forum “Arctic: Present and Future”, St. Petersburg, 2017;

2. IV All-Russian Congress of UNESCO Chairs, Kazan - March 7, 2019;

3. International conferences in Syktyvkar and the city of Khanty - Mansiysk,March 2019, where the Indigenous Peoples Languages Year was opened under the auspices of UNESCO; 
4. International Scientific and Practical Conference "Indigenous Languages as a Factor in the Sustainable Development of the Arctic", Yakutsk, June 27-29, 2019;

5. International Conference on Preservation of World Languages in Cyberspace: Context, Politics, Practice", Yakutsk, July 2019;

6. International forum "Northern Sustainable Development Forum" (NSDF), Yakutsk, September 24-28, 2019.

At these conferences, various problems and approaches to the preservation and development of the linguistic and cultural diversity of humankind were discussed. During discussions of these issues, the idea came to expand the project on an international scale. Project called "Digitalization of Linguistic and Cultural Heritage of Indigenous Peoples of the Arctic" with the focus, not only on indigenous peoples of the Russian Federation, but also in all countries of the Arctic zone of the world.

The goal of the project is to document, preserve and develop the linguistic and cultural diversity of the indigenous peoples of the Arctic on digital media and create a multicultural communication environment in the global information spaceto promote the processes of sustainable development of indigenous peoples of the Arctic in modern conditions.

\section{Project Objectives:}

1. To form an international team of contributing participants including all countries of the Arctic zone;

2. In each country, to organize expeditions to places of compact residence of the indigenous peoples of the Arctic, to make video and photographs of native speakers among the older generation, and to find people who have archival materials (photos, audio, video and other archival documents on cultural and the historical heritage);

3. To create a unified, constantly updating knowledge base on the indigenous peoples and a multicultural environment for communication and education on the global Internet, based on the Arctic multilingual portal www.arctic-megapedia.ru in cooperation and with a link to the www.arcticportal.org, www.arctic-council.org and other relevant portals and websites;

4. To create conditions for mobile electronic education of residents of the Arctic regions, taking into account the nomadic lifestyle;

5. Achieve the goals of sustainable development of the peoples of the Arctic in the context of globalization.

The project will be implemented in the following stages: Preparatory (July-September 2020), Main (October 2020 - June 2023) and Final (July-December 2023). The project has the 
Internationalization of languages and culture of indigenous peoples of the arctic in the... Anatoly Zhozhikov \& Borisova Isabella Zakharovna

support of the Russian Association of Indigenous Peoples of the North.

\section{Expected results:}

1. Invaluable records of disappearing native speakers of the indigenous language and culture will be obtained, and unique archival materials will be collected;

2. All indigenous peoples of the Arctic will be represented on the Arctic multilingual Internet portal www.arctic-megapedia.ru, which will allow integrating indigenous peoples into the international information format;

3. A unified structured knowledge base will be created for all the indigenous peoples, which will allow to learn from each other and preserve and develop the language, original culture and traditional way of life;

4. The Internet will create a multicultural environment for communication between peoples living in the Arctic;

5. There will be an opportunity to use the most current digital technologies of mobile electronic education to train future personnel for the Arctic regions, taking into account the nomadic lifestyle;

6. Conditions to achieve the goals of sustainable development of the peoples of the Arctic in the context of globalization will be created.

Partners: Institute of Circumpolar Reindeer Husbandry, University of the Arctic (Norway), Arctic Portal (Iceland), ARCTICenter (USA).

The project was presented at a meeting of the Arctic Council via videoconference on December 17, 2019, where 15 representatives of countries and members of the Arctic Council took part. The project was supported and included in the international projects proposal from Russia, which will be submitted for review and selection at a meeting of the Arctic Council Sustainable Development Working Group in Akureyri (Iceland) March 22, 2020.

In connection with the orientation of the project on an international scale, the following approaches were used to internationalize our project.

If you look at the term "internationalization" in the Big explanatory dictionary of the Russian language [6], then Internationalization is " Recognition something as international; the transformation of something into the object of international law; granting under an agreement to all states the right to use on an equal footing some object (channel, territory, etc.).

At the same time, as another author notes in his article [7], the terms "internationalization" and "localization" initially appeared in computer science, when there was a need for localization of sites and software. With the spread of computers and the Internet in all spheres of human life, these terms have found their expression in other areas of science, and they no 
longer boil down to the field of computer technology. Internationalization is one of the prerequisites for localization. Through internationalization, we are expanding the scope of use of the source, rather than its content. The advantage of internationalization is easier and faster localization. Internationalization without localization does not make sense. Due to internationalization, a localized product will be suitable for any market in any language and in any culture.

Wikipedia(https://ru.wikipedia.org/wiki)providesthefollowingterm"Internationalizationtechnological development methods that facilitate the adaptation of the product (such as a software or hardware ) to the linguistic and cultural characteristics of the region (regions) different from the one in which the product was developed."

Summarizing these three terms let's consider what signs of internationalization have been used in our project "Digitalization of the Linguistic and Cultural Heritage of Indigenous Peoples of the Arctic" The first term is quite suitable, since our project goes internationally and includes all the Arctic countries of the world. To date, participation in the project has been confirmed by Iceland and Alaska (USA). In the future, all countries that are members of the Arctic Council will be co-leaders.

The terminology and approaches of the second author are also fully suitable, since the development and implementation of the multilingual portal www.arctic-megapedia. ru connected with computer technology and the global Internet. Localization in our project is the creation of local regional Internet resources related to the indigenous peoples of the North and the Arctic, a specific Arctic region. All localized Internet resources about the language and culture of the indigenous peoples of the North and the Arctic of each region and country will be posted on the portal www.arctic-megapedia.ru and will be available to all interested in these resources . Internationalization will consist in localizing regional Internet resources on the languages and culture of the indigenous peoples of the North and the Arctic on a unified portal. Information on Internet resources will be presented both in native languages and in English, which is the language of international communication.

The term "Internationalization" on Wikipedia is " technological methods of development that simplify the adaptation of a product (such as software or hardware ) to the linguistic and cultural features of a region (s) other than the one in which the product was developed", almost completely reveals the purpose of our international project .

The end result of the project is to achieve that the portal of indigenous peoples www. arctic-megapedia.ru will have become an accessible informational, multicultural educational environment for all indigenous peoples of the North and the Arctic of all countries included in the Arctic zone of the world in order to preserve, develop the languages and original culture of the indigenous peoples of the Arctic. 
In general, a multicultural environment of the 21 st century should appear in the global information space, allowing for a dialogue of civilizations and intercultural cooperation. Multilingual portal has to be part of this multicultural environment and seamlessly integrate the languages and cultures of indigenous peoples of the North and the Arctic to the world information space, so they could fully representtheir people, native language and culture in the multicultural environment of humankind.

In the project, one of the important directions is to promote the sustainable development goals of the indigenous peoples of the Arctic in modern conditions and monitor the achievement of goals. We can talk about the effectiveness of the measures taken by the life change of the indigenous peoples of the North and the Arctic. The project addresses the sustainable development of all indigenous peoples living in the Arctic zone. It should be noted that the unstable situation of indigenous peoples necessitates ensuring their full participation in this process. Therefore, first of all, it is necessary to monitor indicators of sustainable development in the context of indigenous peoples. This will allow us to evaluate the effectiveness of SDGs implementation and adjust public policy.

According to the implementation of the SDGs within the framework of this project, the following can be distinguished:

- SDG3 - promoting a healthy lifestyle for Arctic residents;

- SDG4 - providing inclusive education not only in the state, but also in the native languages of the indigenous peoples, which are on the verge of extinction;

- SDG10 - reducing the digital divide in education and access to information between dominant and minority peoples;

- SDG13 - study and prevention of climate impacts in the Arctic;

- SDG16 - creating a peaceful and open educational environment on the Internet, with access to educational and legal resources and increasing the protection of the legal status of indigenous peoples;

- SDG17 - the project will be implemented as a global international partnership within the framework of the Arctic Council on a wide range of issues related to strengthening the sustainable development of the Arctic indigenous peoples (University of the Arctic, Northern Forum, etc.).

The future of humankind may depend on the successful implementation of these goals: will the process of immersion continue goinginto the abyss of lack of culture, the disappearance of indigenous languages, ignoring the processes of integration into the world space on the principles of equality, or is there still a chance for humanity so that everyone, even the small-numbered people can join into the global information space with a new multicultural communication 
environment in all areas of activity: political, economic, cultural and spiritual life of society for its sustainable development.

\section{References}

BOL'SHOYTOLKOVYYSLOVAR' russkogoyazyka [Large explanatory dictionary of the Russian language] / S.A. KUZNETSOV, 1998. 1536p.

BOL'SHOYTOLKOVYYSLOVAR' russkogoyazyka, s izmeneniyamiidopolneniyami [Large explanatory dictionary of the Russian language, with changes and additions], 2010.

NOVEYSHIYBOL'SHOYTOLKOVYYSLOVAR' russkogoyazyka [Newest large explanatory dictionary of the Russian language]. St.P.-M.: Ripol-Norint, 2008.

PSIKHOLOGIYA Internet-kommunikatsii: uchebnoe posobie [Psychology of Internet communication: manual] / In: E. BELINSKAYA ( ed .). Moscow: MPSU Publ.; Voronezh: MODEK Publ., 2013. p. 192. - (Seriya «Sotsial'naya psikhologiya").

SIGANATULINI.M.Rol'i mestonarodnoypedagogikivformirovaniietnicheskoyidentichnosti [The role and place of folk pedagogy in the formation of ethnic identity] Real'nost' etnosa. Rol' obrazovaniya $\mathrm{v}$ formirovanii etnicheskoy i grazhdanskoyidentichnosti. MaterialyVIII Mezhdunarodnoynauchno-prakticheskoykonferentsii[ Reality of the Ethnos. Materials of the VIII International Scientific Practical Conference]. Saint Petersburg: Asterion Publ., 2006. - pp. 341-344.

SUPRUNOVA L.L. Prioritetnyye napravleniya polikul'turnogo obrazovaniya v sovremennoy rossiyskoy shkole [Priority directions of multicultural education in the modern Russian school] Pedagogika Publ. 2011, no. 4. - pp. 16-28. Translation from the English article by Sarah Bajelani https://termin74.ru/articles/internationalization_2/

YAZYKOVOYE raznoobraziye v Kiberprostranstve: Rossiyskiy i zarubezhnyy opyt. Sbornik analiticheskikh materialov [Linguistic Diversity in Cyberspace: Russian and Foreign Experience. Collection of analytical materials] / E.I. KUZ'MIN, E.V. PLYS. Moscow: MTSBS Publ., 2008. pp. 111- 129.

ZHOZHIKOV A.V., ZHOZHIKOVA S.I. Yazykovoye I kul'turnoyeraznoobraziye korennykh malochislennykh narodov Severa $\mathrm{v}$ vek tsifrovykh tekhnologiy [Linguistic and cultural diversity of indigenous peoples of the North in the digital age] Nauki o kul'ture v perspektive "digital humanities". MaterialyMezhdunarodnoykonferentsii 3-5 oktyabrya 2013, Sankt-Peterburg [Cultural Sciences in "digital humanities" perspective. Materials of the International Conference on October 3-5, 2013, St. Petersburg] / In: L.V. NIKIFOROVA, N.V. NIKIFOROVA (ed.). Saint Petersburg: Asterion Publ., 2013. pp. 438-441. 